\title{
SELECTION OF EVENT MARKETING COMMUNICATION TOOLS IN THE LIGHT OF OWN RESEARCH
}

\author{
URSZULA CHRACCHOL-BARCZYK
}

University of Szczecin, Faculty of Management and Economics of Services, POLAND

e-mail: urszula.chrachol@wzieu.pl

\author{
\begin{tabular}{l|l} 
RECEIVED & 6 November 2018
\end{tabular} \\ ACCEPTED $\quad 3$ December 2018 \\ JEL \\ CLASSIFICATION \\ L82, L86, M31
}

KEYWORDS marketing events, relationship building

ABSTRACT The organization of conferences and events on various topics is a popular tool for transferring specific knowledge, but it also allows for meeting a specific group of people and creates opportunities to build relationships with a group of people who participate in them. When organizing an event, one must decide on the communication tools with which the organizer will want to reach the group interested in the event. Adequate selection may translate into the number of participants in the event. West Pomeranian Agency for Regional Development SA as part of supporting entrepreneurship in Zachodniopomorskie Voivodeship organizes various events, one of them being the Westpomeranian Day of Financial Instruments. The aim of the article is to present the communication tools used by the organizers in relation to their popularity among the participants of the event and to show the importance of event marketing in building relationships. The article uses own research carried out among conference participants on the day it was held.

\section{Introduction}

According to W. Gebhardt and R. Hitzler, events are events that clearly emerge from everyday life, are interactive, mass, organized and usually commercial (Gebhardt, Hitzler, Pfadenhauer, 2000, p. 128). Event marketing is understood as a promotional tool, consisting in organizing various types of mass events serving the 
company's goals towards the external and internal environment. Due to its bidirectionality, it is considered as one of the most effective communication tools (Kolber, 2009).

The interactive nature of event marketing allows to create and strengthen relationships, especially emotional ones. It can strengthen or radically change the brand image. During the event, the recipient devotes enough time and attention to the product or brand to get tied emotionally with the product and the brand. Event marketing has a unique feature - two-part structure. Thanks to events organized, it allows to influence selected entities by presenting their own ideas. (Wanagos, 2010, p. 577).

Each organized event requires a decision on how to inform potential participants of the event about its occurrence. The choice of forms of marketing communication depends on many factors:

- financial resources for this purpose,

- target group, the event is dedicated to,

- spatial coverage of promotional activities.

Thanks to the media, the institution can reach the mass recipient with low costs. Cooperation with the local press or the national press is also of great importance. If we want to reach a specific group from the environment, we can also choose specialized magazines (Budzyński, 2018, p. 38). Skilful use of marketing communication instruments allows participants to provide the necessary information about the institution, and allows them to receive information from the market. A well-organized and attractive event will definitely be remembered by the participants and, above all, can contribute to the institution's success (Olejniczak, 2013, p. 15).

The gathering of a large audience at such an event is a difficult matter. Entrepreneurs are currently offering many such events on various topics and very often they are also free. This often results in the fact that entrepreneurs register for events but as a consequence they do not come to them. Organizers also often have the feeling that entrepreneurs do not take seriously free conferences and sign up for them, and then they do not come. To make the conference more attractive, the organizers often invite well- known actors, journalists, TV presenters, sports stars, motivational speakers.

From the organizer's point of view, the organization of a conference is a big expense, and the participants not showing up are a waste of a significant part of it. For example, the costs of renting a larger room for all registered persons, preparation of more conference materials, payment of catering for people declaring their willingness to participate in the event.

The Westpomeranian Conference Financial Instruments has been organized annually in Szczecin by the West Pomeranian Regional Development Agency, together with the Marshal Office of the West Pomeranian Voivodeship and the Bank Gospodarstwa Krajowego. It-s addressed to entrepreneurs who would like to learn about the available financial support options on the market for the SMME group. At the conference there are also stands of financial intermediaries from the region offering the discussed financial products.

\section{The organization of this event requires}

Marketing communication tools of the organized event - own research 257 people applied for the conference, while 187 people received conference materials on the day of the conference. Conference participants were surveyed. The research tool was in the form of a survey, which was completed by 124 people. The aim of the research was to gain knowledge from the organizer on the sources the event participants obtained information from, 
in order to better match the communication channels to the group of recipients in the future. It should be added that the research of conference participants was organized for the first time.

The respondents were asked to indicate the sources from which they obtained information about the conference. In this question, many answers could be indicated, because the researched person could have obtained the information from more than one source. The study indicated all sources in which the organizer posted information about the conference. The results of the study are shown in Figure 1.

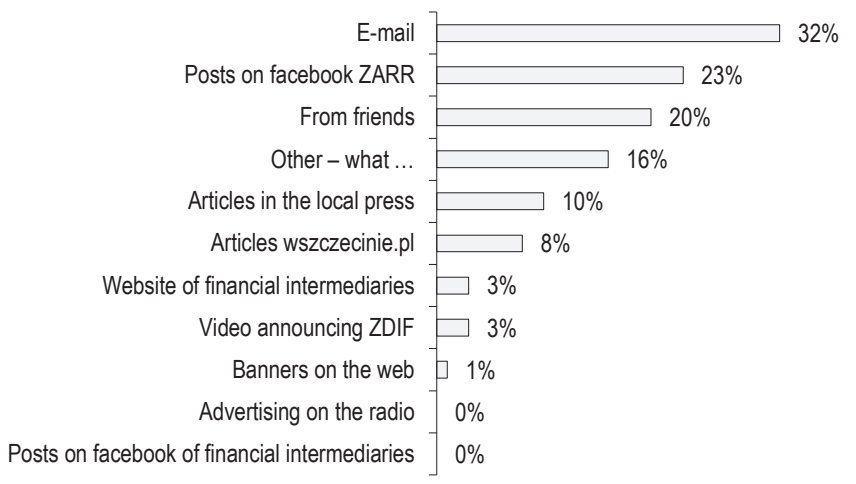

Figure 1. Sources of information on the ZDIF conference (multiple choice question)

Source: own elaboration.

Most of the respondents, as much as $32 \%$, considered that they had learned about the conference from an email message that was sent by the conference organizer. The second source of information included the posts posted on the Facebook of the conference organizer. The information was posted every few days, and each time it was slightly different. The posts included the profiles of individual speakers, descriptions of the workshops accompanying the conference, the address of the conference site where the event had to be registered. Perhaps the person observing the fun page of the organizer was interested in a particular speaker or subject of a particular panel. A slightly smaller group, or $20 \%$, indicated that they learned about the conference from friends. In the business community in Szczecin, own conferences or co-organized by ZARR enjoy increasing popularity and recognition, mainly due to the participation of well-known people and the lack of payment.

Another group, as many as $16 \%$, constituted other sources of information, i.e. the websites of the institutions co-organizing the conference and other parties that shared information about the event in social media or e-mail. It can be clearly stated that sources of information exchanged in the group of others belong to electronic sources websites, e-mail, social media.

Subsequently, the respondents (10\%) indicated articles in the press as a source of information about the conference. Articles and banners (Figure 2) advertising the event were posted in the Szczecin Courier. 


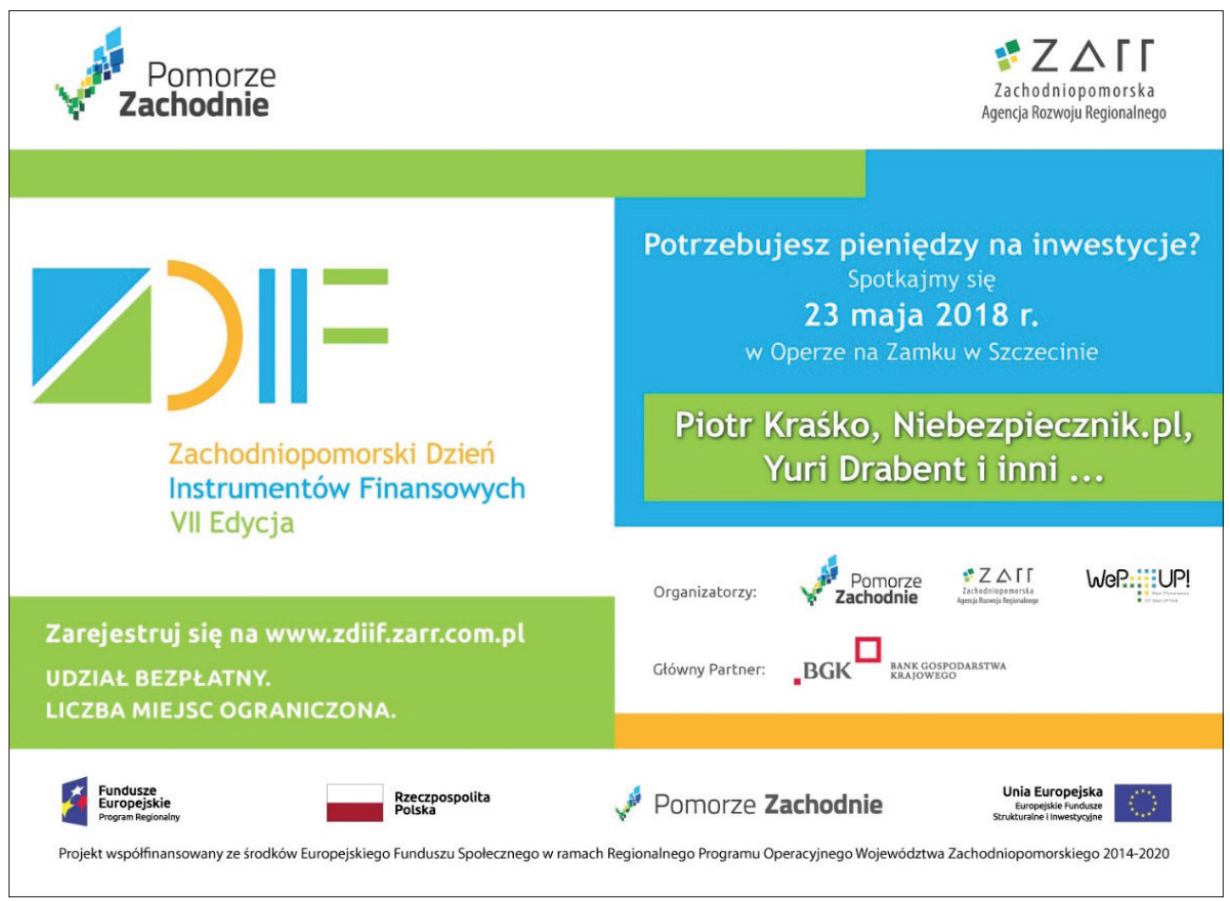

Figure 2. ZDIF conference banner

Source: Office of the Marshal of the West Pomeranian Voivodeship.

Slightly less, because $8 \%$ got an article from wszczecinie.pl. This is a local information portal, posting news and events from Szczecin. The article was on the main page of the portal and was promoted for 7 days on their fun page (48 thousand followers). The results obtained among the subjects do not indicate a good result, however, the statistics of the article are good, as shown in detail in Figure 3 . The post had a reach reach over 44 thousand people, it was displayed by 29 thousand people, 68 people made it available and it had 245 likes. Perhaps the topic of the event did not interest people who saw the post of the conference.

The organizer also prepared a video announcing the event, which inluded: exemplary companies and investments, which received funding for their development and expansion, the announcement of the speakers, the way of registering for the event and its date and place. Then the film was placed on the organizer's Facebook page and in the article on the portal wszczecinie.pl. However, according to the respondents, only $3 \%$ got the information about the conference video. Just as little, because only $1 \%$ of respondents indicated banners posted on the web as the source of information. They were on many local websites with information about events in the city and in the province, business sites of the most popular Polish portals.

Spot on the radio was not indicated by anyone, however, the organizer inserted it deliberately wanting to see if participants remember the source of the knowledge of the event. In the analyzed edition of the conference there was no radio spot at all, it was in the previous edition. 


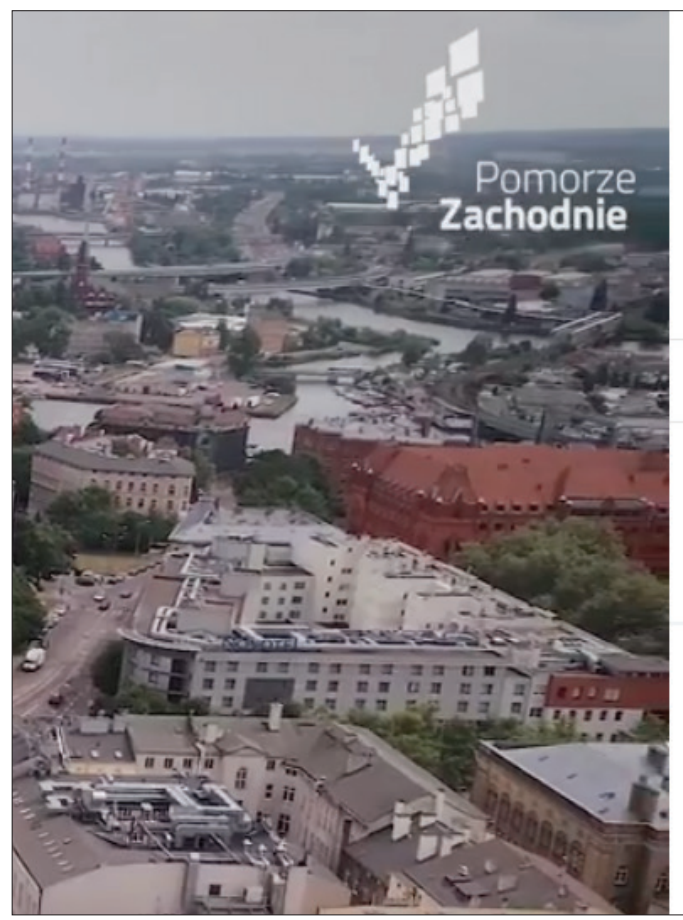

\section{Zachodniopomorski Dzień Instrumentów Finansowych 2018}

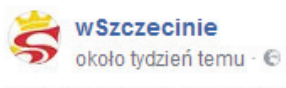

Tak się zmienił Szczecin dziẹki funduszom od Unii Europejskiej $\because$

O tym jak zdo być środki opowiedzą na darmowej konferencji: http://zdiif.zarr.com.pl/\#rejestracja

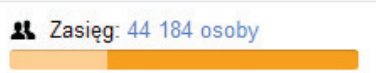

C Zobacz promocje

(1) $=245$

68 udostẹpnień 29 tys. wyświetleń

\section{느 Lubię to!}

Komentarze

$\Leftrightarrow$ Udostępnij

Komentarze

Kolejny film

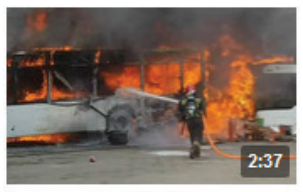

Akcja strażaków - pożar autobusów przy ul. Heyki wSzczecinie Wyświetlenia: 6,3 tys.
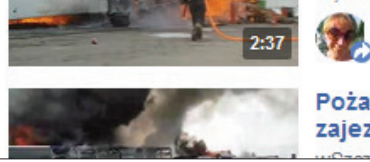

Pożar autobusów w zajezdni na Heyki

Figure 3. The sponsored post on wSzczecinie.pl

Source: https://www.facebook.com/wszczeciniepl.

Summing up the above results, it can be concluded that the majority of respondents received information about the conference through the web, mainly via e-mail or through posts on $\mathrm{fb}$ and from friends.

We can also compare these results with the costs incurred for individual communication channels, and unfortunately, the majority of the paid sources did not translate into their popularity or visibility among the respondents. Banners are the biggest failure, which in the organizer's budget accounted for the largest expenditure.

\section{Conclusions}

The results of the research, from the organizer's point of view, show that they should be carried out in order to more effectively select the communication tools of the organized event and at the same time spend money on them more efficiently. The group of entrepreneurs, which was a group of potential participants of the event, is a very diverse group in terms of age, industries, size of enterprises, etc. Selecting communication tools should take into account many different forms, so as to reach as many recipients as possible and thus get as many registered people as possible for the event. Therefore, the organizer decided to use a variety of different communication tools to make their range as wide as possible.

Thanks to a well-organized event it is possible to promote the organizer of the event and thus gain a group of potential participants of the next event. The entrepreneurs' satisfaction is observed through the actions taken by the organizer of the conference, which makes it easier to recruit participants for the next event. 


\section{Referenences}

Budzyński W. (2018). Public relations. Strategia i nowe techniki kreowania wizerunku. Warszawa: Poltext.

Gebhardt, W., Hitzler, R., Pfadenhauer, M. (2000). Events. Soziologie des Außergewöhnlichen. Opladen: Leske+Budrich.

Kolber D. (2009). Event marketing. Marketing Communication Academy. Retrieved from: http://www.mca.edu.pl/lectorium-czytelniamarketera?start=60.

Olejniczak, A. (2013). Event marketing jako jedna z form innowacji marketingowych w instytucjach naukowych i badawczych. Marketing i Rynek 10, 9-15.

Wanagos, M. (2010). Event marketing w aktywizacji obszarów turystycznych. Acta Scientiarum Polonorum. Oeconomia, 9 (4), $577-584$.

Cite this article aS: Chrąchol-Barczyk, U. (2018). Selection of event marketing communication tools in the light of own research. European Journal of Service Management, 4 (28/1), 55-60. DOI: 10.18276/ejsm.2018.28/1-07. 